\title{
EDITORIAL
}

\section{REFLEXÕES E TECNOLOGIAS NO AMBIENTE DA INFORMAÇÃO}

Prezados leitores,

É com grande satisfação que apresento os artigos deste volume. O número 27 do volume 14 contempla diferentes temáticas que reúnem, de forma organizada, os 11 artigos selecionados. O primeiro texto traz uma reflexão sobre o conceito de "máquina universal", tomando como base os estudos de Pierre Levy sobre tecnologia da informação e cultural digital. O texto que segue relata os resultados de uma pesquisa de doutorado, realizada entre os anos de 2007 e 2008, sobre representações profissionais de bibliotecários em atuação no Brasil. $O$ terceiro artigo tece interessantes considerações a respeito dos desdobramentos oriundos do modelo Requisitos Funcionais para Registros Bibliográficos (FRBR). Em seguida, estão agrupados dois grandes blocos. O primeiro (do $4^{\circ}$ ao $7^{\circ}$ artigo) aborda estudos aplicados aos campos organizacional e judiciário. $\mathrm{O}$ segundo bloco $\left(8^{\circ}\right.$ ao $11^{\circ}$ artigo) explora questões diversas da produção científica.

Desejo uma boa leitura a todos!

Lígia Maria Arruda Café Editora da Revista Encontros Bibli 